\title{
The Postnatal Development of Gut Lamina Propria Lymphocytes: Number, Proliferation, and $T$ and $B$ Cell Subsets in Conventional and Germ-Free Pigs ${ }^{1}$
}

\author{
H. J. ROTHKÖTTER, H. ULBRICH, AND R. PABST
}

Centre of Anatomy, Medical School of Hannover, Hannover, Germany

\begin{abstract}
The lamina propria (LP) contains many lymphocytes that are effector cells as well as memory cells of the gut immune system. This compartment was studied in normal and germ-free pigs in the early postnatal period up to $91 \mathrm{~d}$ of age. The number of LP lymphocytes nearly doubled between the 1st and 29th d. LP lymphocytes proliferated more in the crypt region than in the villi with a mitotic rate/h comparable to that in nonfollicular compartments of Peyer's patches and lymph nodes. The determination of the subpopulations of LP lymphocytes showed a 10-fold increase in $\mathrm{CD} 2^{+}$cells between $\mathrm{d} 1$ and 40 . About $80 \%$ of the LP T cells in 1- and 5-d-old pigs had the unusual $\mathrm{CD2}^{+} \mathrm{CD4}^{-} \mathrm{CD8}^{-}$phenotype. Ig-positive cells appeared later in the postnatal period than the $T$ cells. On $d$ 1 , only a few $\mathrm{IgM}^{+}$cells were observed. In 40-d-old animals, the number of $\mathrm{IgA}^{+}$cells exceeded that of $\mathrm{IgM}^{+}$. Ten times more $\mathrm{Ig}^{+}$cells were detected in the crypt region than in the villi. The germ-free pigs at an age of $49 \mathrm{~d}$ had a $T$ cell subset pattern comparable to that of 5-d-old normal animals. (Pediatr Res 29: 237-242, 1991)
\end{abstract}

Abbreviations

LP, lamina propria

PP, Peyer's patches

TBS, Tris-buffered saline

VCR, vincristine sulphate

The gut immune system is an essential part of the barrier function of the gut wall. The uptake of microbial and nutritional antigens in the gut starts immune responses by initiating either tolerance or a specific secretory immune reaction (for review see refs. 1-4). Large numbers of lymphocytes are distributed in the epithelium and LP of the gut mucosa. Some of the LP lymphocytes are PP-derived B lymphoblasts, becoming mature plasma cells in the LP. They preferentially produce $\operatorname{IgA}(5,6)$. The majority of $\mathrm{T}$ cells in the LP are $\mathrm{CD}^{+}(7,8)$. The $\mathrm{T}$ cells show a high expression of genes associated with cell activation (9). The proportion of antigen-primed memory cells is higher in LP $T$ cells than in peripheral blood lymphocytes (reviewed in 4).

In the early postnatal period, the gut wall is exposed to microbial antigens for the first time. Additionally, the amount of

Received April 11, 1990; accepted October 9, 1990

Correspondence: Dr. H. J. Rothkötter, Zentrum Anatomie 4150, Medizinische Hochschule Hannover, Postfach 610180, D-3000 Hannover 61, Germany.

Supported by the Deutsche Forschungsgemeinschaft, "Gastrointestinal Barrier," Project C 1.

Presented in part at the 5th International Congress of Mucosal Immunology. London, July 1989. nutritional antigens increases when the mother's milk is gradually replaced by other forms of food (3). Therefore, major changes can be expected in the number and subset composition of lymphocytes in the LP.

In this study, the LP lymphocytes were examined in pigs for several reasons: pigs can be reared under germ-free conditions (10); being omnivorous, pigs have been used in experimental gastroenterology for studying the development of intestinal enzymes (11) as well as mucosal permeability (12); and pigs can serve as animal models for the Campylobacter jejuni infection (13). In the postnatal period in pigs, the size of the organized lymphoid tissue of the gut, the PP, increases dependent on microbial and nutritional antigens, and the lymphocytes proliferate dependent on age (14). In the conventional pig, the lymphocyte subset composition shows major differences in the two types of PP (15), which are absent in germ-free animals.

Our study had the following aims: $I$ ) to determine the number of LP lymphocytes at different ages in the postnatal period, 2) to study whether lymphocytes proliferate locally in the LP, 3) to determine the T and B subpopulations of LP lymphocytes to find out whether there are different patterns of development for each subset, and 4) to study the lymphocyte numbers and subsets under germ-free conditions to get an idea of how microbial antigen influences the development of the LP cells.

\section{MATERIALS AND METHODS}

Animals. Normal and germ-free male and female German landrace pigs of different ages were examined. The animals had been reared in different ways as described earlier (14). The various groups and the different experiments carried out in these groups are listed in Table 1. All animals were killed using an i.v. injection of T 61 (embutramid, mebezoniumjodit, tetracainhydrochlorid; Hoechst Veterinär, Unterschleißheim/Munich, Germany).

Lymphocyte proliferation. These experiments had been done earlier to study lymphocyte proliferation in the PP $(14,16)$. Now tissue samples of the same pigs were used to determine proliferation in the LP. In brief, pigs of $1,5,12,40$, and $91 \mathrm{~d}$ of age were injected with $0.25 \mathrm{mg} / \mathrm{kg}$ body weight of VCR (Eli Lilly, Giessen, Germany) i.v. to arrest all mitoses in the metaphase. At $1,2,2.5$, or $3.5 \mathrm{~h}$ after the VCR injection, the animals were killed. The 13-wk-old animals were laparotomized under anesthesia (Thiopental: Trapanal, Byk-Gulden, Konstanz, Germany) and in every pig samples of the gut were taken for histology before and 1, 2, 2.5, and $3.5 \mathrm{~h}$ after the injection of VCR.

Histology and immunohistology. Pieces of the jejunum and ileum were excised and fixed in Schaffer's solution. The tissue was embedded in glycolmethacrylate, cut at $4 \mu \mathrm{m}$ and stained with Giemsa or hematoxylin and eosin solution. For immunohistology the following method was used as described previously 
Table 1. Animal groups and experimental design

\begin{tabular}{rclccc}
\hline $\begin{array}{c}\text { Age } \\
\text { (d) }\end{array}$ & $\begin{array}{c}\text { Number of } \\
\text { animals }\end{array}$ & $\begin{array}{c}\text { Breeding } \\
\text { conditions }\end{array}$ & $\begin{array}{c}\text { Lymphocyte } \\
\text { number }\end{array}$ & Proliferation & $\begin{array}{c}\text { Lymphocyte } \\
\text { subsets }\end{array}$ \\
\hline 1 & 11 & Conventional & + & + & + \\
5 & 6 & Conventional & + & + \\
5 & 5 & Feeding machine & + & + \\
12 & 9 & Feeding machine & + & + \\
17 & 5 & Feeding machine & + & + \\
21 & 7 & Feeding machine & + & + \\
29 & 12 & Feeding machine & + & + \\
40 & 12 & Feeding machine & + & + \\
91 & 6 & Conventional & Germ-free & + & + \\
49 & 6 & G & + \\
\hline
\end{tabular}

Table 2. MAb used in this study

\begin{tabular}{clcl}
\hline Antibody & Specificity & Reference & Dilution \\
\hline T cells & & & \\
$74-12-4$ & CD4 & 18 & $1: 200$ \\
$295 / 33$ & CD8 & 18 & $1: 30$ \\
$8 / 1$ & Resting T cells & 18 & $1: 400$ \\
Mac80 & CD2 & 18 & $1: 300$ \\
Ig $^{+}$cells & & & \\
27.9 .1 & anti-pig IgA & 18 & $1: 20000$ \\
$23.7 .1 \mathrm{~b}$ & anti-pig IgG & 18 & $1: 20000$ \\
28.4 .1 & anti-pig IgM & 18 & $1: 20000$ \\
\hline
\end{tabular}

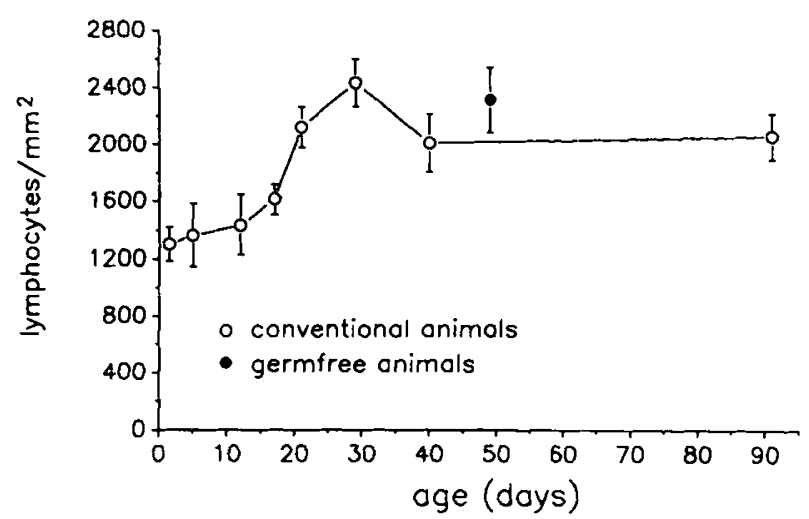

Fig. 1. Number of lymphocytes in the LP of the gut mucosa of conventionally reared pigs of different ages and in germ-free animals 49 $\mathrm{d}$ of age. The results are given as the mean number of cells $/ \mathrm{mm}^{2} \pm \mathrm{SD}$.

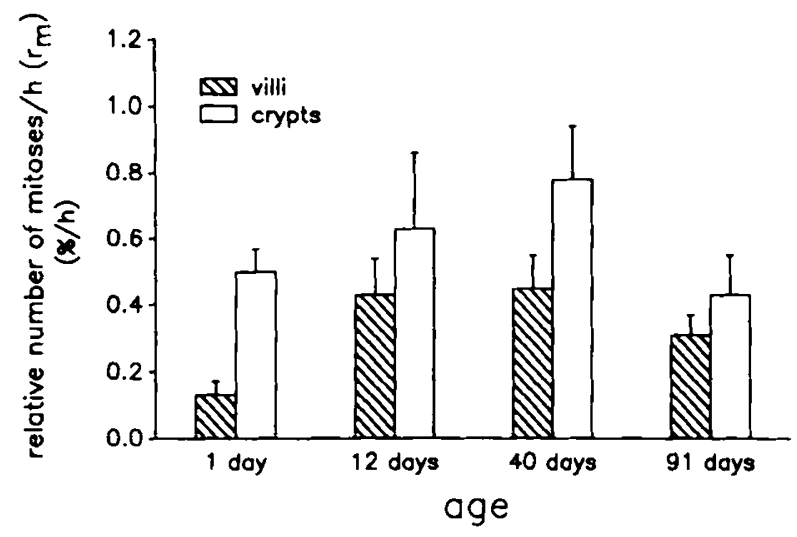

Fig. 2. Relative number of mitoses/h $\left(r_{m}\right)$ in the gut LP after metaphase arrest using vincristine. The results are given as the mean of $r_{m} \pm$ SD. Significant differences are indicated in the text.
(17): Small parts of the gut were frozen in liquid nitrogen and stored at $-70^{\circ} \mathrm{C}$. Cryostat sections $(5 \mu \mathrm{m})$ were cut, dried for at least $1 \mathrm{~h}$, and stored at $-20^{\circ} \mathrm{C}$. After being removed from the freezer, the cryostat sections were dried for $30 \mathrm{~min}$ and then fixed for $90 \mathrm{~s}$ in equal parts of methanol and acetone. TBS containing $0.05 \%$ Tween 20 (Serva, Heidelberg, Germany) served as washing buffer. The sections were incubated with 50 $\mu \mathrm{L}$ of the primary antibody dilution for $30 \mathrm{~min}$ in a humid chamber. The MAb (reviewed in ref. 18) used in this study are listed in Table 2. The sections were incubated with the second (rabbit anti-mouse Ig) and third antibody (alkaline phosphatase anti-alkaline phosphatase complex), both diluted 1:50 (Dako, Hamburg, Germany). The color reaction was carried out with a fast red solution (10 mg fast red salt in $9.8 \mathrm{~mL} 0.1 \mathrm{M}$ TBS containing $2 \mathrm{mg}$ naphthol AS-MX phosphate, $200 \mu \mathrm{L} \mathrm{N}, \mathrm{N}$ dimethylformamide, and $10 \mu \mathrm{L} 1 \mathrm{M}$ levamisole, all from Sigma, Munich, Germany), counterstained, and mounted in glycergel (Dako). For sections of 12- and 40-d-old animals the indirect peroxidase method was used: goat anti-mouse $F^{\prime}(a b)_{2}$ fragments diluted 1:50 served as second antibody and the surface labeling was developed in these sections with 3,3'-diaminobenzidinetetrahydrochloride (Sigma) dissolved in TBS at a concentration of $1 \mathrm{mg} / \mathrm{mL}$ containing $0.02 \% \mathrm{H}_{2} \mathrm{O}_{2}$. These sections were counterstained as described above and mounted. To test whether the sensitivity of both methods was comparable, in six samples both techniques were used. The number of positive cells $/ \mathrm{mm}^{2}$ were similar (40-d-old animals, alkaline phosphatase or peroxidase technique: $\mathrm{CD}^{+}, 1340 \pm 240$ and $1240 \pm 396 ; \mathrm{CD}^{+}, 910 \pm$ 270 and $780 \pm 290$ cells $/ \mathrm{mm}^{2}$ ).

Evaluation. Only cells with all the morphologic characteristics of lymphocytes were counted. A Zeiss microscope was used with an ocular grid containing 100 rectangles (total area, $0.01 \mathrm{~mm}^{2}$ at $625 \times$ magnification). The cell counts were carried out as follows: The grid was moved in the villi or crypt region of the jejunum and ileum. At $625 \times$ magnification, the area of the LP was determined by counting the number of the rectangles placed over the LP. The number of lymphocytes, mitoses, or membranestained lymphocytes in the measured area was counted. The cell number $/ \mathrm{mm}^{2}$ was calculated with the number of the counted rectangles. For the number of lymphocytes and mitoses, at least 50 grids and for lymphocyte subsets at least 20 grids were examined both in the crypt and in the villi region.

Using regression analysis, the relative number of mitoses per $\mathrm{h}$ was calculated, and $p \leq 0.05$ in the two-tailed $t$ test for linear regression was regarded as significant for the relative number of mitoses per $h$. For cell numbers and specific stained lymphocytes the mean number $/ \mathrm{mm}^{2}$ and SD were calculated, the MannWhitney $\mathrm{U}$ test was used, and $p \leq 0.05$ in the two-tailed test was taken as significant.

\section{RESULTS}

Lymphocyte numbers. In the various age groups, no major differences in the lymphocyte numbers were detected between the crypt and villi region or the jejunum and ileum. The cell 


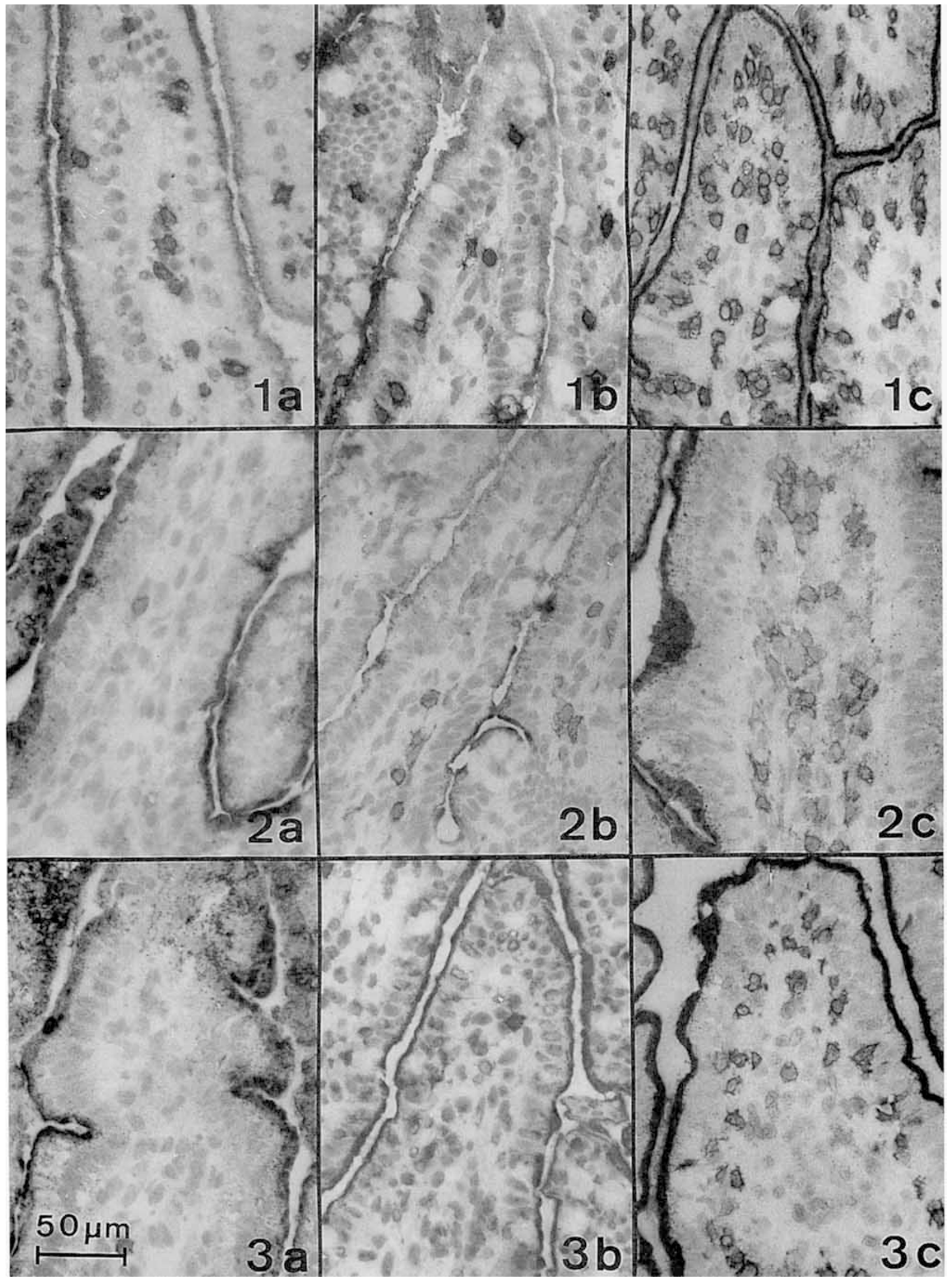

Fig. 3. Immunohistologic illustration of $T$ lymphocyte subsets in the gut epithelium and lamina propria of $1-(a), 5-(b)$, and 40 -d-old $(c)$ pigs. All T cells $\left(\mathrm{CD}^{+}\right)(1), \mathrm{CD}^{+}$cells (2), and $\mathrm{CD} 8^{+}$cells (3). Magnification $290 \times$. 


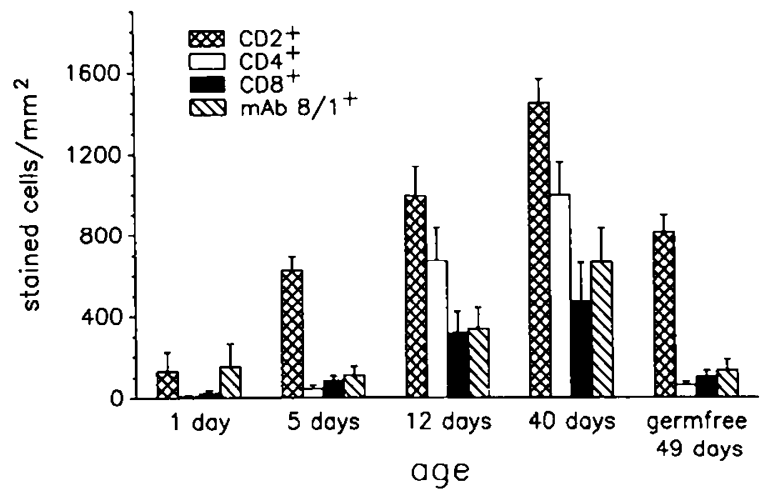

Fig. 4. T lymphocyte subsets in the LP of 1-, 5-, 12-, and 40-d-old conventionally reared pigs and in 49-d-old germ-free pigs. The mean number of positive stained cells $/ \mathrm{mm}^{2} \pm S D$ is given. Significant differences are indicated in the text.

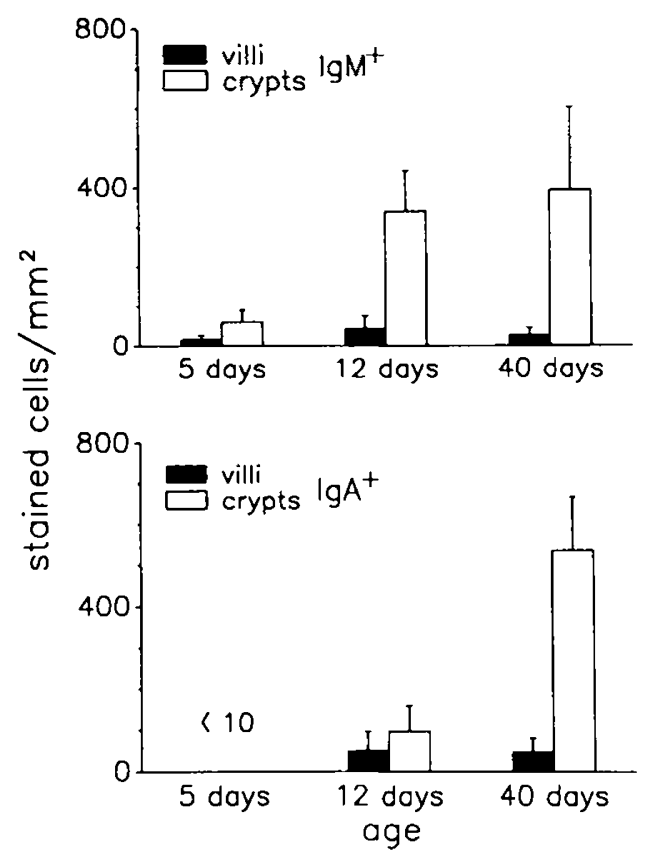

Fig. 5. Number of $\operatorname{IgM}^{+}$and $\operatorname{IgA}{ }^{+}$cells in the LP of 5-, 12-, and 40d-old animals. The results are shown for the villi and crypts, respectively (mean number of cells $/ \mathrm{mm}^{2} \pm \mathrm{SD}$ ).

number increased from $\mathrm{d} 1$ to 29 and remained constant later (Fig. 1). Between $d 1$ and 17, there was no significant increase, whereas in the older animals the numbers were significantly higher. Surprisingly, the number of cells in germ-free animals was comparable to that in age-matched conventional animals. In germ-free animals, there were no differences between the jejunum and ileum or the crypt and villi region.

Cell proliferation. The mitotic rate/ $h$ was comparable in the jejunum and ileum. Significant differences were observed in the mitotic rate/ $h$ in 1-d-old pigs with a higher mitotic rate/ $h$ in the crypt than in the villi region (Fig. 2). Such differences had disappeared in the older animals. However, the mitotic rate/h in the villi of 1-d-old animals was lower than that in the villi of 12 $\mathrm{d}$-old and in the crypts and villi of 40-d-old animals. Thus, the local lymphocyte proliferation showed an increase with age only in the LP of the villi.

$T$ lymphocyte subsets. The immunohistologic examination showed that almost all intraepithelial lymphocytes bear the CD8 molecule, whereas in the LP the T cells are preferentially $\mathrm{CD}^{+}$ (Fig. 3). Accessory cells positive for CD4 were not detected in the LP. The 1-d-old normal and 49-d-old germ-free animals had very low numbers of intraepithelial lymphocytes (Fig. 3). Con-

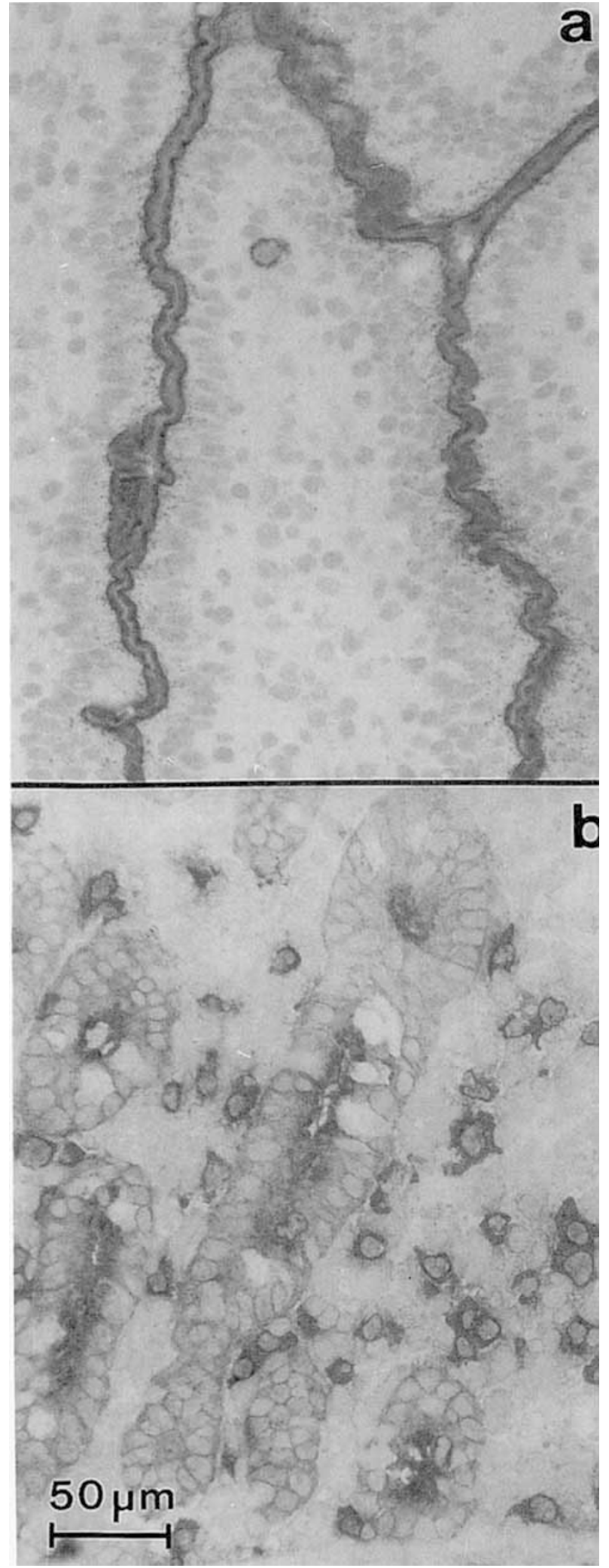

Fig. 6. Immunohistologic illustration of the distribution of $\operatorname{IgA}{ }^{+}$cells in the LP of the gut. Villi $(a)$ and crypts $(b)$ of a 40-d-old pig. Magnification $290 \times$.

cerning the $T$ cell subsets, no major differences were observed between the crypt and villi region or the jejunum and ileum; therefore, the results determined in these compartments were combined (Fig. 4). The number of $\mathrm{CD}^{+}$cells increased rapidly during postnatal development. The $\mathrm{T}$ cell subsets showed the 
following pattern: the $\mathrm{CD}^{+}$cells increased from $\mathrm{d} 1$ to 40 about 150 times and the number of $\mathrm{CD}^{+}$cells increased by a factor of 20 (Fig. 4). The differences among the age groups were significant. There was indication of a subset of $\mathrm{CD} 2^{+} \mathrm{CD} 4^{-} \mathrm{CD} 8^{-} \mathrm{LP}$ lymphocytes in the very young pig. The relative frequency of this subset was calculated by adding the number of $\mathrm{CD4}^{+}$and $\mathrm{CD}^{+}$cells and comparing their sum to the $\mathrm{CD} 2^{+}$cells. The calculation revealed that in 1 - and 5-d-old animals, between 59 and $88 \%$ of the $\mathrm{CD} 2^{+}$cells had neither $\mathrm{CD} 4$ nor $\mathrm{CD} 8$ on their surfaces. This $\mathrm{CD} 2^{+} \mathrm{CD} 4^{-} \mathrm{CD} 8^{-}$subset disappeared from $\mathrm{d} 12$ onward. The proportion of cells positive for the $\mathrm{MAb} 8 / 1$ was always lower than the number of $\mathrm{CD}^{+}$cells.

Of particular interest was the subset distribution in the LP of 49-d-old germ-free animals. With respect to all subsets, the pattern was comparable to that of 5-d-old conventional animals (Fig. 4), but significantly different from the pattern of conventional animals of similar age.

$B$ cell subsets. In all animal groups, hardly any $\mathrm{IgG}^{+}$cells were detected. In the LP of the gut of 5-d-old animals, only IgM $^{+}$cells were found (Fig. 5). In the older animals, highly significant differences between crypts and villi were observed. $\operatorname{IgA}{ }^{+}$cells appeared for the first time in the LP of 12-d-old pigs (Fig. 5) without significant differences in their localization. Their number rapidly increased until d 40 when their number was 10 times higher in the crypts than in the villi (Figs. 5 and 6). In contrast, in the LP of germ-free animals only a very small number of $\mathrm{Ig}^{+}$ cells was detected and this was too low to calculate the number/ $\mathrm{mm}^{2}$ with sufficient accuracy.

\section{DISCUSSION}

The method described for LP cell counts was used earlier and gives the density of cells $/ \mathrm{mm}^{2}(8,19)$. Although the overall size of the LP increases during the postnatal development, this method was sensitive enough because the cell densities in the various age groups were different. The number of lymphocytes increased, showing an adaptation of the gut wall to the high amount of antigen in the gut lumen. Between d 12 and 29, a rapid increase in the cell number was observed, which corresponds to the rapid growth of the PP in the same period previously observed in pigs (14). The mitotic rate per h was comparable to the rate in nonfollicular compartments of lymphoid organs, e.g. PP $(14,16)$. The observation of dividing lymphocytes in the LP provides evidence that a certain proportion of LP lymphocytes develops locally.

So far there are no published data about the subset distribution of LP lymphocytes in very young animals. The number of $T$ cells increased dramatically with age and the distribution of the $T$ cell subsets showed an unusual pattern. In normal 1- to 5-dold pigs and in germ-free 49-d-old animals, calculations revealed that a high proportion of lymphocytes had the $\mathrm{CD} 2^{+} \mathrm{CD} 4^{-} \mathrm{CD} 8^{-}$ subset. In a recent study, $15 \%$ of the $T$ cells in the blood of pigs also had this subtype (20). In the PP of germ-free minipigs, the relative number of $\mathrm{CD}^{+} \mathrm{CD}^{-} \mathrm{CD} 8^{-}$cells was about $20 \%$ (15). In the human fetal gut, a comparable $T$ cell subset was described recently (21). However, these $\mathrm{CD}^{+}{ }^{+} \mathrm{CD} 4^{-} \mathrm{CD} 8{ }^{-}$lymphocytes expressing the $\gamma / \delta$-T cell receptor were mainly located in the epithelium of the gut mucosa. Further studies with double labeling of these lymphocytes using different markers are necessary to understand this unexpected lymphocyte population.

A high number of $\mathrm{CD} 2^{+}$lymphocytes were negative for the molecule stained by the MAb $8 / 1$, which provides evidence that LP T cells are highly stimulated (22). In LP lymphocytes, the expression of genes associated with cell activation was reported in nonhuman primates (9). In normal animals of 12 and $40 \mathrm{~d}$ of age, the $T$ subset distribution in the LP was comparable to that reported earlier in man $(7,8,23)$

A new aspect in this study was the distribution of $\mathrm{LP} \mathrm{Ig}^{+}$cells in germ-free animals. As the cell number was very low, no distinction was made between membrane and cytoplasmic stain in the $\mathrm{Ig}^{+}$cells. The appearance of $\mathrm{Ig}^{+}$cells in normal animals was comparable to results reported earlier (24). Perkkiö and Savilahti (19) reported a similar pattern of appearance of Ig isotypes in children after birth. One additional aspect is the preferential localization of $\mathrm{Ig}^{+}$cells in the crypt region of the LP. However, the typical localization, especially near the crypt openings, as reported by Baklien and Brandtzaeg (25) was not observed. The fact that $\mathrm{Ig}^{+}$cells settle 10 times more often in the crypt region than in the villi should be kept in mind in further experiments. Surface biopsies of the gut wall alone are not representative of all subpopulations of the LP cells.

The results of our study showed a rapid development of the LP lymphocytes in the early postnatal period. Also, dramatic changes occurred, especially in the T lymphocyte subsets, showing an adaptation to the high amount of microbial and nutritional antigen that the gut wall is exposed to. The results in the germ-free piglets provide evidence that the major changes in the LP are due to the microbial antigen in the gut lumen.

Acknowledgments. The authors thank Dr. K. Petzoldt, Veterinary School of Hannover, for offering us the intestines of the germ-free pigs and Dr. F. Klobasa, Institute for Animal Breeding and Behavior (FAL), Mariensee, Neustadt, for the opportunity to use his pigs. Drs. R. M. Binns (Cambridge, UK), A. Bianchi (Lelystad, The Netherlands), U. Koszinowski, M. Reddehase, and A. Saalmüller (Ulm and Tübingen, Germany) kindly supplied us with ascites containing the different antibodies. The skillful technical assistance of M. Peter, S. Schlecht, and A. Skupin and the correction of the English and secretarial help by S. Fryk are gratefully acknowledged.

\section{REFERENCES}

1. Bienenstock J, Befus AD 1980 Mucosal immunology. Immunology 41:249_ 270

2. Pabst R 1987 The anatomical basis for the immune function of the gut. Anat Embryol (Berl) 176:135-144

3. Schreiber RA, Walker WA 1988 The gastrointestinal barricr: antigen uptake and perinatal immunity. Ann Allergy 61:3-12

4. Brandtzaeg P, Halstensen TS, Kett K, Krajci P, Kvale D, Rognum TO, Scott $\mathrm{H}$, Sollid LM 1989 Immunobiology and immunopathology of human gut mucosa: humoral immunity and intraepithelial lymphocytes. Gastroenterology 97:1562-1584

5. Allen WD Porter $P 1977$ The relative frequencies and distribution of immunoglobulin-bearing cells in the intestinal mucosa of neonatal and weaned pigs and their significance in the development of secretory immunity. Immunology 32:819-824

6. Brandtzaeg P, Valnes K, Scott H. Rognum TO. Bjerke K. Baklien K 1985 The human gastrointestinal secretory immune system in health and disease. Scand J Gastroenterol [Suppl] [ 14:17-38

7. Selby WS, Janossy G, Bofill M. Jewell DP 1984 Intestinal lymphocyte subpopulations in inflammatory bowel disease: an analysis by immunohistological and cell isolation techniques. Gut 25:32-40

8. Hirata I, Berrebi G Austin LL, Keren DF Dobbins WO 1986 Immunohistological characterization of intraepithelial and lamina propria lymphocytes in control ileum and colon and in inflammatory bowel disease. Dig Dis Sci 31:593-603

9. Zeitz M. Greene WC, Peffer NJ, James SP 1988 Lymphocytes isolated from the intestinal lamina propria of normal nonhuman primates have increased expression of genes associated with T-cell activation. Gastroenterology 94:647-655

10. Dziaba KA, Lambrecht G, Petzoldt K 1985 Intestinal and serum antibody response in gnotobiotic piglets to oral immunization with Escherichia coli. Comp Immunol Microbiol Infect Dis 8:267-272

11. Shulman RJ, Henning SJ, Nichols BL 1988 The miniature pig as an animal model for the study of intestinal enzyme development. Pediatr Res 23:311315

12. Crissinger KD, Granger DN 1989 Mucosal injury induced by ischemia and reperfusion in the piglet intestine: influences of age and feeding. Gastroenterology 97:920-926

13. Boosinger TR, Powe TA 1988 Campylohacter jejuni infections in gnotobiotic pigs. Am J Vet Res 49:456-458

14. Pabsi R, Geist M, Rothkotter HJ, Fritz FJ 1988 Postnatal development and lymphocyte production of jejunal and ileal Peyer's patches in normal and gnotobiotic pigs. Immunology 64:539-544

15. Rothkötter HJ, Pabst R 1989 Lymphocyte subsets in jejunal and ileal Peyer's patches of normal and gnotobiotic minipigs. Immunology 67:103-108

16. Pabst R, Fritz FJ 1986 Comparison of lymphocyte production in lymphoid organs and their compartments using the metaphase-arrest technique. Cell Tissue Res 245:423-430 
17. Westermann J, Ronneberg S, Fritz FJ, Pabst R 1989 Proliferation of lymphocyte subsets in the adult rat: a comparison of different lymphoid organs. Eur J Immunol 19:1087-1093

18. Lunney JK, Pescovitz MD 1988 Differentiation antigens of swine lymphoid tissues. In: Miyasaka M, Trnka $Z$ (eds) Differentiation Antigens in Lymphohemopoietic Tissues. Dekker, New York, pp 421-454

19. Perkkiö M, Savilahti E 1980 Time of appearance of immunoglobulin-containing cells in the mucosa of the neonatal intestine. Pediatr Res 14:953-955

20. Saalmüller A, Reddehase MJ, Bühring HJ, Jonjič S, Koszinowski UH 1987 Simultaneous expression of CD4 and CD8 antigens by a substantial proportion of resting porcine T lymphocytes. Eur J Immunol 17:1297-1301

21. Spencer J, Walker-Smith JA, Isaacson PG, MacDonald TT 1989 Heterogeneity in intraepithelial lymphocyte subpopulations in fetal and post-natal human small intestine. J Paediatr Gastroenterol Nutr 9:173-177
22. Saalmüller A, Jonjič S, Bühring HJ, Reddehase MJ, Koszinowski UH 1987 Monoclonal antibodies reactive with swine lymphocytes. II. Detection of an antigen on resting $\mathrm{T}$ cells down-regulated after activation. $\mathrm{J}$ Immunol 138:1852-1857

23. Jenkins D, Goodall A, Scott B 1989 T-cell and plasma cell populations in coeliac small intestinal mucosa in relation to dermatitis herpetiformis. Gut 30:955-958

24. Butler JE, Klobasa F, Werhahn E 1981 The differential localization of IgA, IgM and $\operatorname{lgG}$ in the gut of suckled neonatal piglets. Vet Immunol Immunopathol 2:53-65

25. Baklien K, Brandtzaeg $P 1976$ Immunohistochemical characterization of local immunoglobulin formation in Crohn's disease of the ileum. Scand J Gastroenterol 11:447-457

\section{Announcement}

\section{Annual Meeting of the European Society for Pediatric Research 1991}

The European Society for Pediatric Research (ESPR) will hold its next meeting in Zürich, Switzerland, September 1-4, 1991. The European Society of Pediatric Allergy and Clinical Immunology and the European Society of Magnetic Resonance in Neuropediatrics will join the ESPR. Satellite postgraduate courses and a symposium will be organized by these two societies on September 1 and September 5.

The main topics of the ESPR meeting are: therapeutic interventions in immune-mediated diseases, connective tissue, energy metabolism, and circulation of the neonatal brain.

Deadline for submitting abstracts is April 15, 1991.

For information, contact: Gabriel Duc, University Hospital of Zürich, Frauenklinikstrasse 10, ZH-8091 Zürich, Tel. + 4112555340 , Telefax + 4112554442 . 